\title{
Computer Tomography as a Tool for Physical Analysis in an Anthropogenic Soil
}

\author{
Hyen Chung Chun, Chan Won Park, Yeon Kyu Sonn*, Hyun Joon Cho, Byung Keun Hyun, \\ Kwan Cheol Song, and Yong Seon Zhang
}

National Academy of Agricultural Science, RDA, 441-707, Suwon-city, Gyeonggi-do, Korea

(Received: November 4 2013, Accepted: November 25 2013)

\begin{abstract}
Human influence on soil formation has dramatically increased as the development of human civilization and industry. Increase of anthropogenic soils induced research of those soils; classification, chemical and physical characteristics and plant growth of anthropogenic soils. However there have been no reports on soil pore properties from the anthropogenic soils so far. Therefore the objectives of this study were to test computer tomography (CT) to characterize physical properties of an anthropogenic paddy field soil and to find differences between natural and anthropogenic paddy field soils. Soil samples of a natural paddy field were taken from Ansung, Gyeonggi-do (Ansung site), and samples of an anthropogenic paddy field were from Gumi in Gyeongsangnam-do (Gasan) where paddy fields were remodeled in 2011-2012. Samples were taken at three different depths and analyzed for routine physical properties and CT scans. CT scan provided 3 dimensional images to calculate pore size, length and tortuosity of soil pores. Fractal analysis was applied to quantify pore structure within soil images. The results of measured physical properties (bulk density, porosity) did not show differences across depths and sites, but hardness and water content had differences. These differences repeated within the results of pore morphology. Top soil samples from both sites had greater pore numbers and sizes than others. Fractal analyses showed that top soils had more heterogeneous pore structures than others. The bottom layer of the Gasan site showed more degradation of pore properties than ploughpan and bottom layers from the Ansung site. These results concluded that anthropogenic soils may have more degraded pore properties as depth increases. The remodeled paddy fields may need more fundamental remediation to improve physical conditions. This study suggests that pore analyses using CT can provide important information of physical conditions from anthropogenic soils.
\end{abstract}

Key words: Anthropogenic soils, Computer tomography, Fractal dimension

Summary of fractal dimension (D) values from Ansung and Gasan sites at three different depths.

\begin{tabular}{ccc|ccc}
\hline \hline Sites & Layer & $\mathrm{D}$ & Sites & Layer & $\mathrm{D}$ \\
\hline \multirow{3}{*}{ Ansung } & top & 1.99 & & top & 1.91 \\
& ploughpan & 1.56 & Gasan & boundary & 1.73 \\
& bottom & 1.74 & & bottom & 1.68 \\
\hline
\end{tabular}

*Corresponding author : Phone: +821038590704, E-mail: sonnyk@korea.kr

${ }^{\S}$ Acknowledgement: Acknowledgement: This study was supported by NAAS research and development project (project number: PJ008620) 


\section{Introduction}

토양은 오랜 시간에 걸쳐 암석이 풍화를 거쳐 생성되는 것으로 토양 생성에 영향 주는 요소들 중에는 시간, 물, 지 형, 생물, 기후 등을 꼽을 수 있다 (Brady and Well 1996). 지난 수십 년 간, 급격한 인구 증가, 집약적 농업활동, 화학 비료의 투입과 중장비 기계의 발달은 표토 뿐만 아닌 심토 부분까지 토양 형성 및 발달에 막대하게 영향을 주기 시작 하였다 (Bidwell and Hole 1965), 인위토양이란 자연토양 상 태에서 토양 층위나 토양 분류에 변화를 줄 수 있는 정도의 인위적 영향이 있는 경우 인위토양으로 규정하고 있다 (Dudal et al., 2002). 우리 나라에서는 현재까지 조사된 인위토양 의 종류는 매립형 인위토양과 적토형 인위토양으로 나뉘어 진다. 매립형 인위토양은 원토양을 걷어낸 후 준설토를 하 부에 쌓고 그위에 다시 원토양을 덮는 형태의 토양이다. 적 토형은 원토양 위에 준설토를 쌓아 올려놓는 형태이다. 이 러한 인위토양은 자연상태의 원토양과 비교해 보면 토양 내 부까지 물리성과 화학성의 변화를 일으켰고, 이런 인위토양 특성들을 고려해서 토양관리에 차별을 두어야 한다는 연구 발표가 이루어지고 있다 (Dudal et al., 2002; Volungevičius and Skorupskas 2011). 현재까지 인위토양에 대한 연구는 다 양한 분야에서 이루어져 왔다. 인위토양의 분류 (Dudal et al., 2002; Volungevičius and Skorupskas 2011; Avery 1980; Blume 1989), 인위토양의 이화학적 특성 (Hur et al., 2008; Ibrahim et al., 2012; Massoura et al., 2006; Sonn et al., 2012) 인위토양이 식물에 미치는 영향 (Renison et al., 2004), 인 위토양에서 미생물과 작물의 생육에 미치는 영향 (Liang et al., 2003) 등이 있다. 여러 논문들에 공통적으로 결론지어지 는 부분은 인위토양이 물리성, 화학성뿐만 아닌 토양 내 미 생물학 분포의 다양성으로도 자연토양에 비해 퇴화되는 양 상을 보이고 있다는 것이다. 특히 물리성을 살펴보면 토양 내부에 급변층의 생성에 의하여 배수불량을 일으킨다고 밝 혀져 왔다 (Ibrahim et al., 2011). 현재까지는 이런 물리성 과 화학성의 퇴화나 급격한 변화에 대해 명확하고 구체적인 연구가 없었고 이러한 이유로 문제점에 대한 뚜렷한 해결책 이 제시되고 있지 않고 있다.

토양 내부는 단순한 토양 입자들의 집합체가 아닌 생성 조건에 따라 다양한 구조를 보여주고 있다. 토양 내부 구조 의 다양성은 토양입자와 공극의 나열 모양에 따라 결정되어 진다 (Dexter 1988). 공극 구조의 형태는 토양 내 물, 공기, 비료 등이 이동하는 통로이므로 공극 구조 분석은 토양 내 물과 양분이동까지 예측할 수 있는 지표가 되고 토양 내부 구조 발달 상태를 알려주기도 한다 (Chun et al., 2008). 이 런 토양 내부 구조를 관찰하는 방법으로 비파괴적이면서 삼 차원적 분석이 가능한 Computer Tomography (CT)가 이용 되어 지고 있다 (Peth et al., 2008). CT 촬영으로 얻어지는
토양의 삼차원적 이미지를 통하여 토양 공극의 다양한 정량 적 특성을 분석할 수 있게 되었다. 토양 공극의 크기, 공극 의 부피, 굴곡도, 길이 등이 있다 (Al-Raoush and Willson 2005). 또한 이를 바탕으로 토양 수분의 특성 또한 예측할 수 있다 (Baveye et al., 2002; Peth et al., 2008). 이러한 공극의 정량적 특성뿐만 아닌 삼차원 이미지를 통해 공극 구조의 다양성 또한 계산이 가능하다. 현재까지 인위토양 내부를 CT 촬영하여 공극 분석을 한 연구는 발표되어지지 않았다.

이번 연구는 $\mathrm{CT}$ 촬영을 통해 인위토양 농경지와 일반 농 경지의 깊이별 물리성과 공극구조 특성을 규명하고 $\mathrm{CT}$ 촬 영 방법이 두 토양간 차이점을 밝힐 수 있는 분석방법이 될 수 있다는 것이다. 이를 위해서 이번 연구의 목표는 4대강 사업으로 조성된 리모델링 농경지 한곳과 일반 농경지 한곳 을 깊이 별로 시료 채취하여 기본 물리성을 측정 비교하고 $\mathrm{CT}$ 촬영을 통한 공극구조의 정량화을 계산였다.

\section{Materials and Methods}

본 연구에 사용된 시험포장은 경기도 평택시 소사동 411 에 위치한 하성평탄지 토양으로서 (안성포장, Ansung) 최근 10년동안 객토나 적토한 적이 없는 농경지이다. 두번째 시험 포장은 구미시 도개면 가산리에 위치한 매립적토형 인위토 양으로 (가산포장, Gasan) 토성은 사양토로 되어 있고 2012 년 4대강 리모델링 사업의 완료로 다시 논으로 이용되어지 는 곳이다 (sonn et al., 2012). 본 연구에서 시험포장 선정 시 가장 중요한 요소로 토양 형성 상태였다. 리모델링 농경 지의 경우 표토와 준설토의 토성만 맞으면 형성과정과 시기

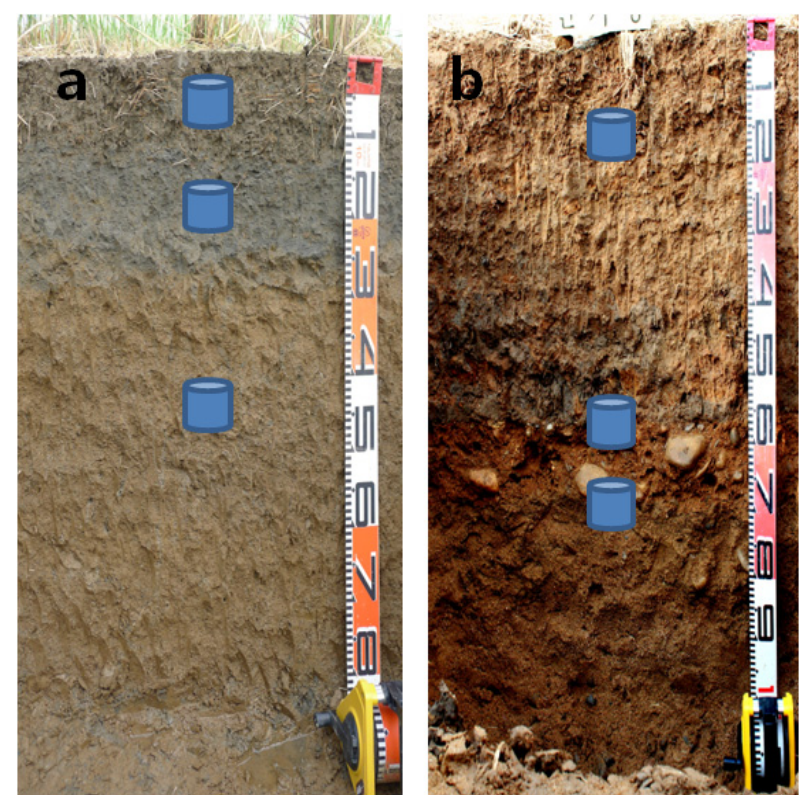

Fig. 1. Soil profiles and sampling locations (blue cylinder): a. Natural soil (Ansung) and b. anthropogenic soil (Gasan) site. 
를 알기 때문에 시험포장 선정이 쉬웠다 2012년 리모델링 농 경지 토양조사결과 전체 4 대강 리모델링 농경지 중 가장 넓 은 면적을 차지하는 토양형성 상태는 표토에 사양토와 준설 토에 사토로 이루어진 형태였고 이로 인하여 가산포장이 선 정되었다. 반면 일반토양은 근 10년 동안 객토나 적토한 적이 없으며 표토가 사양토와 비슷한 토성을 갖고 있는 토양을 찾기가 쉽지 않았다. 그에 따라 앞의 조건들을 충족시키며 농경지의 역사를 확실히 알고 있는 안성포장이 선정되었다.

시료 채취는 안성 포장과 가산포장에서 $1 \mathrm{~m}$ 정도의 토양 단면을 파내어 깊이별로 시료 채취를 하였다. 안성포장은 토양조사 결과를 바탕으로 표토층 (top, 0 10 cm), B1층 (쟁 기바닥층, ploughpan, 15 25 cm), B2인 심토층 (subsoil, $40 \mathrm{~cm}$ 이하)에서 시료채취를 하였다 (Fig. 1(a)). 반면 가산포장은 리 모델링 농경지로 표토 약 $50 \mathrm{~cm}$ 와 그 밑의 준설토로 나뉘어 진다. 표토 (top, 0 20 cm), 경계면 (interference, $55 \sim 65 \mathrm{~cm}$ ), 준설토 (subsoil, $65 \mathrm{~cm}$ 이하) 에서 시료채취가 이루어 졌다 (Fig. 1(b)). 현장에서 시료 채취 깊이별 경도와 수분함량을 측정하였고 각 지점에서 일반 물리성 분석 시료, 2 인치 코 어와 $\mathrm{CT}$ 촬영용 코어 (지름 $5 \mathrm{~cm}$, 높이 $10 \mathrm{~cm}$ ) 시료들을 채 취하였다. 경도와 수분함량은 조사 현장에서 10 반복으로 각 층위별로 측정되었다. 일반 물리성 분석은 모두 3 반복으로 토성, 용적밀도 등 농촌진흥청 토양 및 식물체분석법(NIAST, 2000)에 준하여 분석을 하였으며, CT 촬영은 한국건설기술 연구원 (일산, 경기도)에 분석 의뢰하였다. 한국건설기술연 구원에서 직접 주문제작된 multi $\mathrm{x}$-ray 영상시스템으로 촬 영 조건은 $90 \mathrm{kV}$ 에서 $0.043 \mathrm{~mm}$ 의 해상도였다. 여기서 생 성된 이미지들은 믹셀 (mixing pixel) 모델의 thresholding과 filtering을 거쳐서 binary 이미지들 (21.5 x $21.5 \times 43 \mathrm{~mm}$ ) 로 보정되어졌다 (Kobayashi et al., 2009) (Fig. 2). 이런 이 미지들의 과정은 Image J (Research Services Branch, National Institute of Health, Bethesda, MD)에서 이루어 졌다. 공극 의 크기, 길이와 표면적 등은 porenetwork 방법으로 계산되 었다 (Peth et al., 2008). 또한 공극 구조의 정량화를 위해 fractal 분석은 다음과 같이 계산되었다 (Gimenez et al., 1997).

$$
N_{f}(L)=K L^{-D}
$$

$$
\begin{array}{ll}
\mathrm{D} & \text { : fractal dimension } \\
\mathrm{N}_{\mathrm{f}}(\mathrm{L}) & \text { : number of pores at cell size } \mathrm{L} \\
\mathrm{K} & : \text { a number of initiators of unit length, and } \\
& \text { assumed to be as } 1
\end{array}
$$

삼차원 토양 이미지에서 fractal 분석은 Fortran 프로그 램에서 계산되었다. 모든 측정치 결과들은 AVOVA (IBM SPSS, $\mathrm{NY}, \mathrm{USA}$ )를 이용하여 통계처리 되었다.
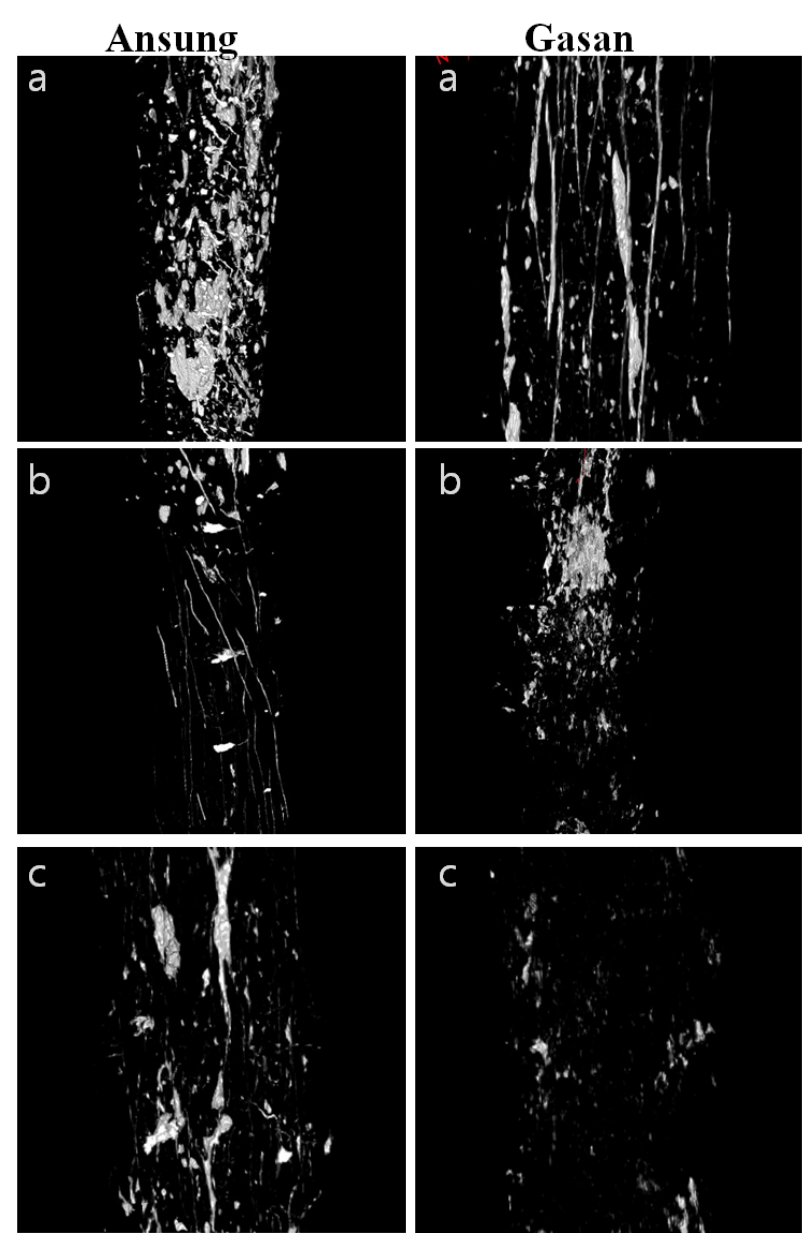

Fig. 2. Three dimensional images of natural (Ansung) and anthropogenic (Gasan) soil sites at depths: 1) Ansung site - a. top $(0 \sim 10 \mathrm{~cm})$, b. ploughpan $(15 \sim 25 \mathrm{~cm})$ and c. subsoil layer $(>40 \mathrm{~cm}), 2)$ Gasan site - a. top $(0 \sim 20 \mathrm{~cm})$, b. interference $(55 \sim 65 \mathrm{~cm})$, and c. subsoil layer $(>65 \mathrm{~cm})$. White represents pore in soil.

\section{Results and Discussion}

경기도 평택시 소사동에 위치한 안성 논 포장은 표토층 인 Ap1층이 0-13 cm까지 분포하였고 토성은 양토로 토색은 주로 암회색으로 배수등급이 “약간불량”인 보통답이었다. 깊이 13-27 cm 까지는 쟁기바닥층으로 역시 암회색을 띄며 양토였다. 그 이후의 층들은 B층으로 이루어져서 갈색을 띄 며 양토에서 미사질양토로 이루어져 있었다.

구미시 도개면 가산리에 위치한 포장은 표토 약 $60 \mathrm{~cm}$ 를 걷어낸 뒤 약 $3 \mathrm{~m}$ 의 강바닥 준설토를 적토한 후 걷어낸 원 토양을 다시 위에 적토한 상태의 토양이었다. 맨 위의 원토 양의 표토는 교란된 상태로 다시 적토되었다.

각 시험포장에서 채취한 시료들에 대한 기본 물리성 측 정 결과는 Table 1에 나타내었다. 안성과 가산포장 두 곳은 표토층 토성이 각 양토와 사양토로 가산포장이 모래함량이 더 많다. 위에서 설명한대로 안성은 $20 \mathrm{~cm}$ 이하에 약 $10 \mathrm{~cm}$ 
Table 1. Summary of physical properties from natural (Ansung) and anthropogenic (Gasan) soil sites at different depths: 1) Ansung site - a. top (0 10 cm), b. ploughpan $(15 \sim 25 \mathrm{~cm})$ and c. subsoil layer $(>40 \mathrm{~cm}), 2)$ Gasan site - a. top $(0 \sim 20 \mathrm{~cm})$, b. interference $(55 \sim 65 \mathrm{~cm})$, and c. subsoil layer $(>65 \mathrm{~cm})$.

\begin{tabular}{|c|c|c|c|c|c|c|c|c|}
\hline Sites & Layer & Texture & $\begin{array}{c}\text { Sand } \\
(\%)\end{array}$ & $\begin{array}{l}\text { Clay } \\
(\%)\end{array}$ & $\begin{array}{l}\text { Bulk Density } \\
\left(\mathrm{g} / \mathrm{cm}^{3}\right)\end{array}$ & Porosity & Hardness $(\mathrm{mm})$ & $\begin{array}{l}\text { Water content } \\
\qquad\left(\mathrm{m}^{3} / \mathrm{m}^{3}\right)\end{array}$ \\
\hline \multirow{3}{*}{ Ansung } & top & Loam & 37.6 & 13.9 & $1.47 \pm 0.05$ & $44.46 \pm 1.72$ & $14.40 \pm 1.78^{\mathrm{a}^{*} \dagger}$ & $0.26 \pm 0.02^{\mathrm{a}^{*}}$ \\
\hline & ploughpan & Loam & 35.8 & 13.3 & $1.55 \pm 0.01$ & $41.34 \pm 0.36$ & $22.90 \pm 1.66^{\mathrm{b}}$ & $0.17 \pm 0.04^{\mathrm{b}^{*}}$ \\
\hline & subsoil & Silt Loam & 25.5 & 16.9 & $1.47 \pm 0.02$ & $44.60 \pm 0.78$ & $17.00 \pm 1.69^{\mathrm{c}}$ & $0.32 \pm 0.02^{\mathrm{c}^{*}}$ \\
\hline \multirow{3}{*}{ Gasan } & top & $\begin{array}{l}\text { Sandy } \\
\text { Loam }\end{array}$ & 68.9 & 8.8 & $1.71 \pm 0.03$ & $35.59 \pm 1.08$ & $8.90 \pm 1.10^{\mathrm{a}^{*}}$ & $0.16 \pm 0.02^{\mathrm{a}^{*}}$ \\
\hline & interference & $\begin{array}{l}\text { Sandy } \\
\text { Loam }\end{array}$ & 62.8 & 12.0 & $1.63 \pm 0.07$ & $38.50 \pm 2.81$ & $22.90 \pm 1.73^{\mathrm{b}}$ & $0.02 \pm 0.00^{b^{*}}$ \\
\hline & subsoil & Sand & 94.4 & 3.6 & $1.50 \pm 0.06$ & $43.33 \pm 2.26$ & $8.90 \pm 2.23^{\mathrm{a}}$ & $0.03 \pm 0.03^{\mathrm{b}^{*}}$ \\
\hline
\end{tabular}

$\dagger \mathrm{a}, \mathrm{b}, \mathrm{c}$ : differences at $95 \%$ among three depth layers within a site.

*: differences at $95 \%$ between the same depth layer from two sites.

Table 2. Summary of pore morphological properties from natural (Ansung) and anthropogenic (Gasan) soil sites at different depths: 1) Ansung site - a. top $(0 \sim 10 \mathrm{~cm})$, b. ploughpan $(15 \sim 25 \mathrm{~cm})$ and c. subsoil layer $(>40 \mathrm{~cm}), 2)$ Gasan site - a. top (0 20 cm), b. interference $(55 \sim 65 \mathrm{~cm})$, and c. subsoil layer $(>65 \mathrm{~cm})$.

\begin{tabular}{ccccccc}
\hline \hline \multirow{2}{*}{ Sites } & Layer & $\begin{array}{c}\text { Number of } \\
\text { pores }\end{array}$ & $\begin{array}{c}\text { Average pore size } \\
(\mathrm{mm})\end{array}$ & $\begin{array}{c}\text { Average pore } \\
\text { length }(\mathrm{mm})\end{array}$ & $\begin{array}{c}\text { Average pore } \\
\text { tortuosity }(\mathrm{mm})\end{array}$ & $\begin{array}{c}\text { Average surface } \\
\text { area }(\mathrm{mm})\end{array}$ \\
\hline \multirow{3}{*}{ Ansung } & top & 6665.00 & $1.22 \pm 0.06^{\mathrm{a}^{* \dagger}}$ & $0.70 \pm 0.60^{\mathrm{a}^{*}}$ & $1.31 \pm 0.77$ & $0.92 \pm 3.24^{\mathrm{a}^{*}}$ \\
& ploughpan & 14713.00 & $0.80 \pm 0.37^{\mathrm{b}^{*}}$ & $1.38 \pm 1.44^{\mathrm{b}^{*}}$ & $1.215 \pm 0.21$ & $0.22 \pm 1.40^{\mathrm{b}}$ \\
& subsoil & 7384.00 & $0.65 \pm 0.35^{\mathrm{c}^{*}}$ & $1.01 \pm 1.66^{\mathrm{b}^{*}}$ & $1.23 \pm 0.25$ & $0.21 \pm 0.59^{\mathrm{b}^{*}}$ \\
& top & 1965.00 & $1.15 \pm 0.37^{\mathrm{a}^{*}}$ & $1.20 \pm 1.42^{\mathrm{a}^{*}}$ & $1.23 \pm 0.15$ & $0.19 \pm 0.46^{\mathrm{a}^{*}}$ \\
\multirow{3}{*}{ Gasan } & interference & 12594.00 & $0.85 \pm 0.83^{\mathrm{b}^{*}}$ & $0.63 \pm 0.46^{\mathrm{b}^{*}}$ & $1.25 \pm 0.28$ & $0.11 \pm 0.59^{\mathrm{b}}$ \\
& subsoil & 3647.00 & $0.82 \pm 0.54^{\mathrm{b}^{*}}$ & $0.49 \pm 0.35^{\mathrm{b}^{*}}$ & $1.23 \pm 0.20$ & $0.09 \pm 0.40^{\mathrm{b}^{*}}$ \\
\hline
\end{tabular}

$\dagger$ a, b, c: differences at $95 \%$ among three depth layers within a site.

*: differences at $95 \%$ between the same depth layer from two sites.

정도의 쟁기바닥층이 나왔고 이를 기준으로 그 밑의 심토층 은 토성이 바뀌었다. 반면 가산은 $60 \mathrm{~cm}$ 에서 사양토에서 사 토로 바뀌는 급변층이 형성되어 있다. 안성포장 쟁기바닥층은 표토층과 심토층과 비교해서 용적밀도, 공극률에서 차이를 보 이지 않았다. 그러나 경도와 수분함량은 모두 차이를 보였다 $(\mathrm{p}<0.05)$. 쟁기바닥층이 다른 층들보다 경도도 높고 수분함 량 또한 매우 낮은 것으로 나타났다. 이런 추세는 인위토양인 가산에서도 비슷하게 보여졌다. 경계층은 경도와 수분함량에 서만 차이를 보였는데 $(\mathrm{p}<0.05)$ 안성포장 쟁기바닥층과 마찬 가지로 경도가 표토보다 크고 수분함량이 매우 낮았다. 다만 수분함량의 경우 심토층이 경계층과 유사한 값을 보였다.

Table 2에는 토양 이미지들에서 porenetwork 모델을 통 해 얻어진 공극의 형태에 대한 계산 결과들이 정리되어 있 다. 안성포장에서 공극 수에서는 쟁기바닥층이 다른 층들보 다 더 큰 값을 보인다. 그러나 공극 크기 분포도 (Fig. 3)에 서 잘 나타나듯이 공극 수는 많으나 크기가 고르게 퍼져있 는 것이 아닌 일부 크기 (반경 0.5 1.0 mm)에 집중적으로 모
여있는 것으로 보여진다. 공극 분석에서 나타난 특이사항은 심토층의 차이이다. 일반 농경지나 인위토양 농경지나 경계 층과 쟁기바닥층보다 심토층들이 물리성이 더 좋다고는 할 수 없다. 그러나 일반 농경지인 안성포장의 심토층은 가산 포장의 심토층과 비교하여 공극 수는 월등히 더 많으나 공 극 크기에서는 확연히 더 작았다. 그러나 공극 길이와 표면적 값에서 안성포장 심토층이 확연하게 더 좋았다 $(\mathrm{p}<0.05)$. 이 는 안성포장 심토층의 공극들이 크기는 상대적으로 가산 심 토층보다 작으나 연결상태가 좋고 토양 내 더 넓은 공간을 공극이 차지하고 있다는 것으로 해석된다. 이와 같은 결과 는 수분함량에서 (Table 1) 안성포장 심토층이 가산포장 심 토층보다 월등히 많은 수분을 함유하고 있는 것도 이런 공 극 구조가 존재하고 있기에 가능한 것이었다.

가산포장의 심토층은 공극의 수가 작으나 존재하는 공극 의 크기가 경계층과 유사한 것으로 보여진다. 그러나 공극 크기, 길이, 굴곡도 등을 종합적으로 보면 이미지 (Fig. 2(c)) 에서 나타나듯이 심토층의 공극은 자연적으로 생성되는 공 

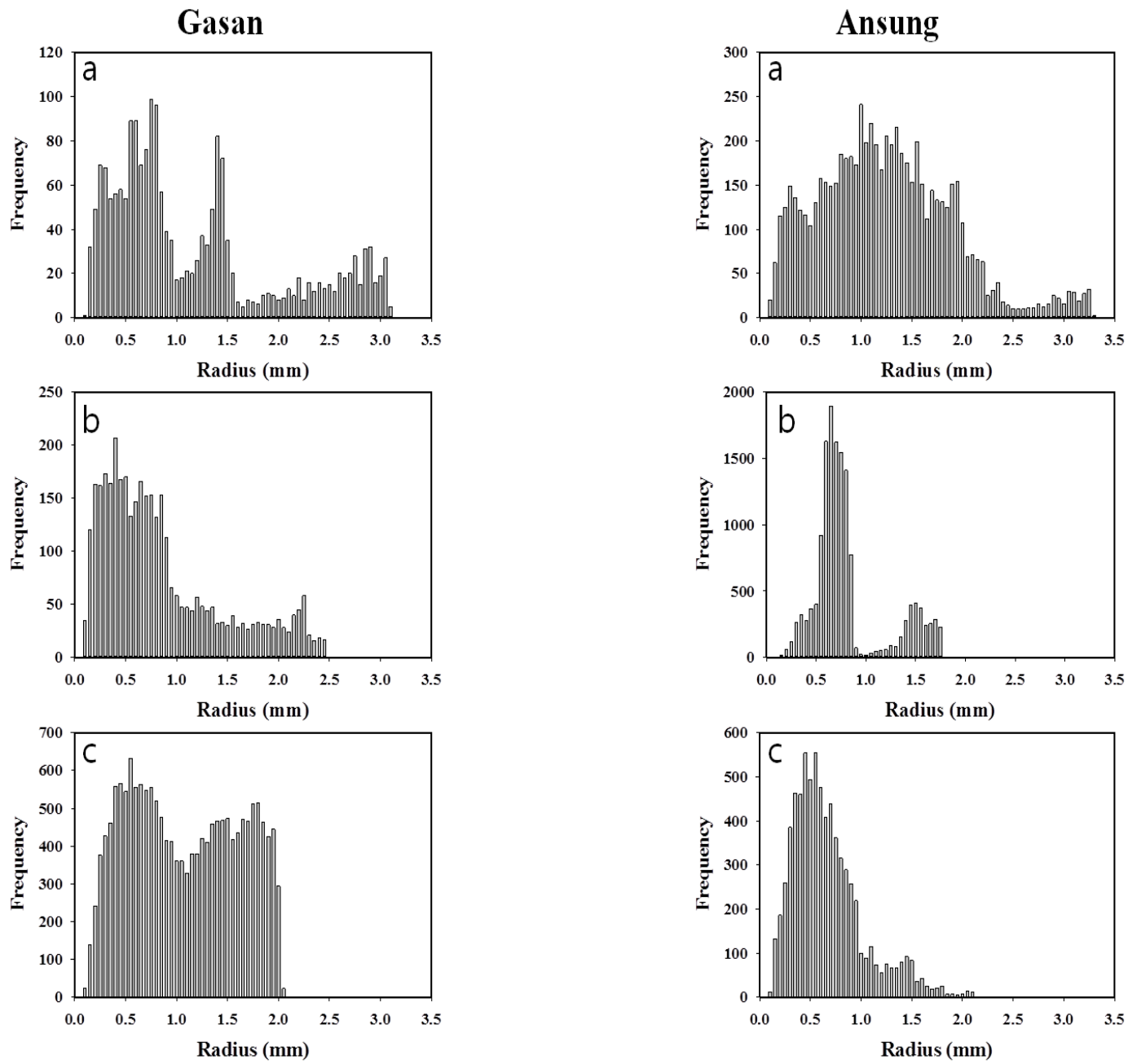

Fig. 3. Pore size distributions from three dimensional images of Ansung and Gasan sites at different depths:1) Ansung site - a. top $(0 \sim 10 \mathrm{~cm})$, b. ploughpan $(15 \sim 25 \mathrm{~cm})$ and c. subsoil layer $(>40 \mathrm{~cm}), 2)$ Gasan site - a. top $(0 \sim 20 \mathrm{~cm})$, b. interference $(55 \sim 65 \mathrm{~cm})$, and c. subsoil layer $(>65 \mathrm{~cm})$.

극의 형태와는 다르게 공극들이 끊어지거나 작은 공극들이 흩어져서 분포하는 형태를 보이고 있다. 즉 기존 공극들이 뿌리와 물의 흐름들에 의해 형성되어 길이가 길게 형성되어 지나, 가산포장의 경계층과 심토층의 공극들은 길이가 짧아 매우 단편적이고 단조로운 구조를 보여주고 있다. 이는 fractal 분석에서 뒷받침되고 있다.

Fractal dimension (D)은 기존 많은 연구에서 잘 정의되 어 왔다. $\mathrm{D}$ 값은 공극구조의 다양성을 정량적으로 표현하는 값이다 (Gimenez et al., 1997). 더 다양한 크기들의 공극으 로 이루어진 공극 구조를 가진 토양의 경우 $\mathrm{D}$ 값은 증가하고 반면 단일한 크기의 공극들로만 이루어진 공극구조는 $\mathrm{D}$ 값 이 감소한다. 이 연구에서 D 값은 식 (1)을 바탕으로 모든 이 미지에서 cell 크기 1 에서 100 pixel 범위 내에서 계산되었 다 (Table 3). 두 포장들 모두 표토층이 다른 층들보다 다양 한 공극의 발달을 보여주고 있다. 안성포장은 D값이 표토층 $>$ 심토층 > 쟁기바닥층 순으로 나타나고 가산포장은 표토층 $>$ 경계층> 심토층 순으로 나타났다. 인위토양의 심토층의
Table 3. Summary of fractal dimension (D) values from natural (Ansung) and anthropogenic (Gasan) soil sites at different depths: 1) Ansung site - a. top (0 10 cm), b. ploughpan $(15 \sim 25 \mathrm{~cm})$ and $\mathrm{c}$. subsoil layer $(>40 \mathrm{~cm}), 2)$ Gasan site - a. top $(0 \sim 20 \mathrm{~cm})$, b. interference $(55 \sim 65 \mathrm{~cm})$, and c. subsoil layer $(>65 \mathrm{~cm})$.

\begin{tabular}{ccc|ccc}
\hline \hline Sites & Layer & $\mathrm{D}$ & Sites & Layer & $\mathrm{D}$ \\
\hline & top & 1.99 & & top & 1.91 \\
Ansung & ploughpan & 1.56 & Gasan & boundary & 1.73 \\
& bottom & 1.74 & & bottom & 1.68 \\
\hline
\end{tabular}

경우 공극 구조 또는 공극 분포에서 극히 단조로움을 보이 고 있는 것이 다른 층들뿐만 아닌 일반 농경지 토양들과 비 교 시 가장 두드러지는 점일 것이다. 가산의 심토층은 안성 의 쟁기바닥층과 비슷한 양상을 보이고 있다. Sonn et al. (2012)에서 설명한 바와 같이 4대강 리모델링 농경지로 조 성된 인위토양 심토층은 공사 시 중장비를 이용한 평탄화 
작업을 반복적으로 이루어지다 보니 공극 구조가 매우 단순 화 되어지고 심토층 내부에 존재하는 공극들 또한 배수와 작물흡수에는 도움을 크게 주지 않는 형태를 보여주고 있 다. 공극 구조의 파괴는 배수불량이나 양분흐름 등을 방해 하여 이를 개선하기 위해 심토파쇄와 같은 방법을 시행하나 보통 이럴 경우 표토에서 $30 \mathrm{~cm}$ 정도까지 파쇄작업을 한다. 일반 농경지의 쟁기바닥층은 보통 $30 \mathrm{~cm}$ 보다 얕은 곳에서 형성되므로 심토파쇄 등으로 토양 물리성을 향상시킬 수 있 으나, 조사지역과 같은 인위토양은 약 $50 \mathrm{~cm}$ 보다 깊은 곳이 물리성 악화를 보이고 있으므로 좀 더 근본적인 해결책이 필요한 것으로 여겨진다.

$\mathrm{CT}$ 촬영 방법은 비파괴적인 방법이면서 토양 내 공극을 직접적으로 관찰 할 수 있는 방법이다. 위에 보여진 결과들 과 같이 4 대강 리모델링 농경지의 토양은 다짐과 적토로 인 한 공극 구조의 파괴와 공극 연결성의 악화를 알 수 있게 하 였다. 이와 같이 토양 내부 공극의 상태를 일반 물리성 측정 과 함께 CT 촬영 방법을 병행하는 것은 토양 내부를 종합적 으로 파악하는데 많은 도움이 될 것이다.

\section{Conclusion}

이번 연구는 일반 농경지와 4대강 리모델링 사업으로 조 성된 인위토양 농경지의 물리성을 깊이별로 분석하였다. 일 반 물리성 분석에서는 각 깊이별로 또는 조사포장들 간에 차이가 크게 보이지 않았다. 반면 CT를 이용한 공극구조 형 상학적 분석에서는 두 포장의 차이점이 잘 보여졌다. 특히 인위토양의 심토층이 일반 농경지의 심토층보다 토성으로 는 순수 모래층에 가까우나 공극구조는 쟁기바닥층에 더 가 깝고 공극 형태가 주로 자갈의 영향을 많이 받은 것으로 나 타났다. CT 촬영으로 얻어진 공극의 형태학적 자료들은 차 후 토양 내 수분의 이동 등과 같은 수문학적 데이터를 얻는 데 도움이 될 것이다. 또한 좀 더 다양한 토성으로 이루어진 인위토양 농경지의 이화학성 특성 연구를 통해 인위토양 농 경지의 관리방안 및 문제점 해결을 제시할 수 있을 것이다.

\section{References}

Al-Raoush, R.I. and C.S. Willson. 2005. Extraction of physically realistic pore network properties from three-dimensional synchrotron X-ray microtomography images of unconsolidated porous media systems. Journal of Hydrology 300(1-4):44-64. Avery, B.W. 1980. Soil classification for England and Wales, p. 67, Harpenden.

Baveye, P., H. Rogasik, O. Wendroth, I. Onasch, and J.W. Crawford. 2002. Effect of sampling volume on the measurement of soil physical properties: Simulation with X-ray tomography data. Measurement Science and Technology 13(5):775-784.
Bidwell, O.W. and F.D. Hole. 1965. Man as factor of soil formation. Soil Science 99:65-72.

Blume, H.P. 1989. Classification of soils in urban agglomerations. Catena Cremlingen 16:269-275.

Brady, N.C. and R.R. Well. 1996. The nature and properties of soils. Pearson Prentice Hall, Ohio.

Chun, H.C., D. Gimenez, and S.W. Yoon. 2008. Morphology, lacunarity and entropy of intra-aggregate pores: Aggregate size and soil management effects. Geoderma 146(1-2):83-93.

Dexter, A.R. 1988. Advances in characterization of soil structure. Soil \& Tillage Research 11:199-238.

Dudal, R., F.O. Nachtergaele, and M.F. Purnell. 2002. The human factor of soil formation, pp. 14-21S, Thailand.

Eom, K.C., P.K. Jung, M.H. Koh, S.H. Kim, S.Y. Yoo, S.H. Park, S.O. Hur, and S.K. Ha. 2010. Water Saving Irrigation Manual of Spring Chinese Cabbage. Korean J. Soil Sci. Fert. 43(6): 812-822.

Gimenez, D., R.R. Allmaras, E.A. Nater, and D.R. Huggins. 1997. Fractal dimensions for volume and surface of interaggregate pores - scale effects. Geoderma 77(1):19-38.

Hur, S.O., Y.K. Sonn, K.J. Lee, S.T. Lee, C.W. Park, S.H. Jeon, S.K. Ha, and J.G. Kim. 2008. Water movement characteristics by soil horizon of cumulants Anthrosol in highland, p. 132 Korean J. Soil Sci. Fert. Conference Proceeding.

Ibrahim, M., S.G. Ha, K.H. Han, and Y.S. Zhang. 2011. Physicochemical characteristics of artificially disturbed soils as affected by agricumulants of different textures, pp. 189-190 Korean J. Soil Sci. Fert. Conference Proceeding.

Ibrahim, M., K.H. Han, S.K. Ha, Y.S. Zhang, and S.O. Hur. 2012. Physico-chemical characteristics of disturbed soils affected by accumulate of different texture in south Korea. Sains Malaysiana 41(3):285-291.

Im, J.N. and S.H. Yoo. 1988. Modeling of estimating soil moisture, evapotranspiration and yield of chinese cabbages from meteorological data at different growth stages. Korean J. Soil Sci. Fert. 21(4):386-408.

Kobayashi, Y., S. Kawasaki, M. Kato, T. Mukunoki, and T. Kaneko. 2009. Applicability of a method for evaluation of porosity to biogrouted geomaterials. Journal of MMIJ 125(10):540-546.

Liang, Y., Y. Yang, C. Yang, Q. Shen, J. Zhou, and L. Yang. 2003. Soil enzymatic activity and growth of rice and barley as influenced by organic manure in an anthropogenic soil. Geoderma 115(1-2):149-160.

Massoura, S.T., G. Echevarria, T. Becquer, J. Ghanbaja, E. Leclerc-Cessac, and J. Morel. 2006. Control of nickel availability by nickel bearing minerals in natural and anthropogenic soils. Geoderma 136(1):28-37.

Park, C. S., J. J. Kim, and S. J. Cho. 1983. Analysis of spatial variability for infiltration rate of field soil. Korean J. Soil Sci. Fert. 16(4):305-310.

Park, C. S., J. J. Kim, and S. J. Cho. 1984. Analysis of spatial variability for particle size distribution of field soils. Korean J. 
Soil Sci. Fert. 17(3):212-217.

Peth, S., R. Horn, F. Beckmann, T. Donath, J. Fischer, and A.J.M. Smucker. 2008. Three-dimensional quantification of intraaggregate pore-space features using synchrotron-radiationbased microtomography. Soil Science Society of America Journal 72(4):897-907.

Renison, D., I. Hensen, and A.M. Cingolani. 2004. Anthropogenic soil degradation affects seed viability in Polylepis australis mountain forests of central Argentina. Forest Ecology and Management 196(2-3):327-333.

Sonn, Y.K., Y.S. Zhang, C.W. Park, Y.H. Moon, B.K. Hyun, K.C. Song, and H.C. Chun. 2012. A comparison of spatial variation on anthropogenic soils. Korean Journal od Soil Science and Fertilizer 45(6):897-899.

Volungevičius, J. and R. Skorupskas. 2011. Classification of anthropogenic soil transformation. GEOLOGIJA 53(4):165-177. 